\title{
Effect of gellan gum concentration on the physicochemical, rheological and sensory properties of acerola smoothie
}

\author{
Amanda Rodrigues LEAL ${ }^{1}$, Luiz Eduardo Oliveira HOLANDA², Fernanda Clara Moreira SOARES ${ }^{2}$, \\ Juliana Nascimento da COSTA ${ }^{3}$, Luís Gustavo Lima NASCIMENTO ${ }^{4}$, Jessica Silva do CARMO ${ }^{3}$, Wende Carla da SILVA 5 , \\ Luciana Façanha MARQUES 5 , Paulo Henrique Machado de SOUSA ${ }^{1,2 \star}$ (i)
}

\begin{abstract}
This study aimed to develop an acerola smoothie using gellan gum (GG) as a texture modifier. Samples were developed with three concentrations of GG $(0.1 \%, 0.2 \%, 0.3 \% \mathrm{w} / \mathrm{v})$ and a control sample (without GG). Physicochemical, rheological, and sensory properties were evaluated. The smoothie samples showed increased color intensity than the control, with a tendency to yellow and red colors. However, the hydrocolloid concentration did not affect the samples' pH values (4.13 to 4.17). GG presence favored an increase in the samples' viscosity, classified as pseudoplastic fluid. There was a reduction in vitamin $\mathrm{C}$ in samples with GG (422.18 to $430.49 \mathrm{mg} / 100 \mathrm{~g})$, however, the values remained close to the control $(448.89 \mathrm{mg} / 100 \mathrm{~g})$. There was greater sensory acceptance by the sample with intermediate texture $(0.2 \% \mathrm{GG})$, which obtained a higher frequency for the attributes "homogeneous" and "acerola flavor".
\end{abstract}

Keywords: hydrocolloid; fruit drink; low acylation; fluid gel.

Practical Application: Smoothie with acerola and gellan gum appear as a drink option with nutritional and sensory appeal.

\section{Introduction}

Smoothies are non-alcoholic creamy drink beverages consisting of a mixture of fruits or vegetables and crushed ice, added with yogurt or milk, with high creaminess and semi-liquid consistency. They can be additive-free and without added sugar, fulfilling all the current demands of consumers (Teleszko \& Wojdyło, 2014; Cano-Lamadrid et al., 2018; Fernandez et al., 2019).

The consumer is more aware of the health problems associated with the diet. Therefore, there is a high demand for quality products with simple compositions, which provides health benefits. Thus, there is growing pressure on industries to develop foods that can supply this demand, and in this scenario, smoothies occupy a prominent place (Keenan et al., 2010; Young; Mills \& Norton, 2020).

Various fruits, such as orange, banana, or apple, are widely used to produce commercial smoothies. Besides, other fruits with a high content of nutrients and sensory acceptance can also be incorporated in preparing these products, for example, red fruits (Hurtado et al., 2017). Recent studies have reported the development of smoothie drinks with different types of fruits and vegetables. Cano-Lamadrid et al. (2018) evaluated the storage conditions in the quality of pomegranate smoothies and fruit puree. Ribeiro et al. (2020) elaborated juçara, banana, and strawberry smoothies, which showed high sensory acceptability and contents of phenolic compounds. Camargo et al. (2020) analyzed the sensory acceptance of smoothie-type drinks based on oats associated with strawberries and bananas.

The acerola (Malpighia emarginata D.C.), a fruit originally from the tropical Americas, also called cherry from the Antilles or cherry from Barbados, shows an increasing expansion and economic importance, mainly due to the high content of vitamin C (1000-4000 $\mathrm{mg} / 100 \mathrm{~g}$ in the fresh pulp), high antioxidant activity (90.41 $\mu \mathrm{M} \mathrm{TE} / \mathrm{g}$ for ABTS), carotenoids (371-1881 $\mu \mathrm{g} / 100 \mathrm{~g}$ ), phenolic compounds (256.22-2631.34 mg GAE/100 g), minerals and dietary fibers (Souza et al., 2014; Leffa et al., 2015; Jaeschke, Marczak, \& Mercali, 2016; Lemos et al., 2019; Xu et al., 2020). As it has a reduced shelf life after harvest, part of the fruit is frozen and exported for processing in a variety of products, and another part is processed into pulp and clarified juice, nectars, among others (Albuquerque \& Silva, 2008; Belwal et al., 2018). Thus, acerola has great potential for making smoothie-type beverages, associating the nutritional benefits of the fruit, with its acid flavor, aroma, and color characteristics.

The creamy consistency of smoothies can be achieved by elaborating a fluid gel and incorporating hydrocolloids in low concentrations. Fluid gels can be defined as a suspension of soft gelled particles dispersed in a continuous non-gelled phase,

${ }^{1}$ Departamento de Engenharia de Alimentos, Universidade Federal do Ceará, Fortaleza, CE, Brasil

${ }^{2}$ Instituto de Cultura e Arte, Universidade Federal do Ceará, Fortaleza, CE, Brasil

${ }^{3}$ Instituto Federal de Educação, Ciência e Tecnologia, Campus Sobral, Sobral, CE, Brasil

${ }^{4}$ Departamento de Tecnologia de Alimentos, Universidade Federal de Viçosa, Viçosa, MG, Brazil

${ }^{5}$ Instituto Federal de Educação, Ciência e Tecnologia do Sertão Pernambucano, Campus Salgueiro, Salgueiro, PE, Brasil

*Corresponding author: phmachado@ufc.br. 
functioning as excellent suspending agents (Phillips \& Williams, 2009; Young et al., 2020).

Among the used hydrocolloids, gellan gum (GG) is widely used in beverage systems as an emulsifier and stabilizer (Xu et al., 2019). It is an extracellular polysaccharide produced by Sphingomonas elodea during aerobic fermentation and consists of tetrasaccharide repetition composed of (1-3)- $\beta$ D-glucose, (1-4)- $\beta$-D-glucuronic, (1-4)- $\beta$-D-glucose and (1-4)- $\alpha$-1-laminose. Two forms of GG differ by their degree of acylation: the native form, known as high acyl gellan gum (HAG), and low acyl gellan gum (LAG) which is produced by alkaline treatment of HAG (Funami, 2011; Morris et al., 2012). GG has gelling functions and its gels are firm, translucent, brittle, and stable at low $\mathrm{pH}$ (Zia et al., 2018).

No studies have been found on smoothies based on acerola and GG, formulated as a fluid gel. In this way, the proposal to associate LAG with acerola pulp will contribute to the optimization of the formulation of this type of drink, aiming the development of a product that is easy to prepare with taste and texture characteristics that are attractive to the consumer.

Thus, the study's objective was to develop an acerola smoothie through fluid gels' production using gellan gum to provide a creamy texture and evaluate the effect of this hydrocolloid concentration on the physicochemical, rheological, and sensory characteristics of the elaborated product.

\section{Material and methods}

\subsection{Raw material}

The acerola pulp (Malpighia emarginata DC), unpasteurized, without preservatives, was purchased directly from the manufacturer, a fruit pulp processing company located in Fortaleza, CE, Brazil. The pulp was received frozen in $100 \mathrm{~g}$ packs and was stored at $-18^{\circ} \mathrm{C}$. The hydrocolloid used was low acylation gellan gum (LAG) (CP Kelco ${ }^{\circ}$, Atlanta, GA, USA). In addition, UHT whole milk (Nestlé ${ }^{\circ}$ ) and refined sugar (União ${ }^{\circ}$ ) were purchased in the local market. All the standards reagents and analytical chemicals were purchased from Sigma-Aldrich (St. Louis, Missouri).

\subsection{Elaboration of acerola smoothie formulations}

Smoothie formulations were made from the combination of acerola pulp ( $45 \% \mathrm{v} / \mathrm{v})(6.4 \%(\mathrm{~m} / \mathrm{m}$ dry matter), milk ( $45 \% \mathrm{v} / \mathrm{v})$, $\operatorname{sugar}(10 \% \mathrm{w} / \mathrm{v})$, and GG in three different concentrations $(0.1 \%$, $0.2 \%$ and $0.3 \% \mathrm{w} / \mathrm{v}$ ) to define the best formulation. Besides, a control sample (without GG) was created. GG and sugar were added to the milk, and this mixture was heated to approximately $90 \pm 2{ }^{\circ} \mathrm{C}$ for $20 \mathrm{~s}$ in a food processor (Termomix, PMS-018, Yammi). These conditions of GG proportion, formulation, and temperature were based on Sherafati et al. (2013) and $\mathrm{Xu}$ et al. (2019), with adaptations. After thermal processing, the homogenized acerola pulp was added with the aid of a glass stick. Subsequently, the mixture was poured into a plastic container and stored under refrigeration at $5{ }^{\circ} \mathrm{C}$ for $12 \mathrm{~h}$ to complete the maturation of the gel. After that time, the formed gel was broken with the aid of a mixer for $60 \mathrm{~s}$ to form the fluid gel. The control sample was composed of acerola pulp ( $45 \% \mathrm{v} / \mathrm{v})$, milk ( $45 \% \mathrm{v} / \mathrm{v})$, and sugar $(10 \% \mathrm{w} / \mathrm{v})$ and, for its production, these ingredients were manually homogenized. All smoothie samples were stored at $5{ }^{\circ} \mathrm{C}$ until further analysis.

\subsection{Color properties}

Color coordinates were determined using a colorimeter (ColorQuest XE, Hunterlab, Virginia, EUA), using the coordinate CIELab/CIELch system of $L^{*}, a^{*}, b^{*}$, chroma $\left(c^{*}\right)$ and Hue angle $\left(h^{\circ}\right)$ according to the methodology described by the Association of Official Analytical Chemists (2005), which was calibrated with a white standard before being used.

\subsection{Physicochemical analysis}

The $\mathrm{pH}$ analysis was performed using a digital potentiometer (Modelo 3505-Jenway, UK); the Total Soluble Solids (TSS) were analyzed using a digital refractometer (Modelo Pal-1, AtagoTokyo, Japan); Titratable Acidity (TA) was evaluated by titrating the samples with standard $\mathrm{NaOH}$ solution at 0.1000 mol. $\mathrm{L}^{-1}$, using phenolphthalein as an indicator, and the results were expressed as a percentage of citric acid (Association of Official Analytical Chemists, 2005).

The evaluation of ascorbic acid (AA) was carried out by the titrimetric method, based on the reduction of the indicator 2.6-dichlorophenolindophenol (DFI) to $0.02 \%$ until a permanent light pink color. The sample $(1 \mathrm{~g})$ was diluted in $50 \mathrm{~mL}$ of oxalic acid $0.5 \%(\mathrm{~m} / \mathrm{m})$ and homogenized. Then, $5 \mathrm{~mL}$ of this suspension was diluted to $25 \mathrm{~mL}$ with distilled water and titrated (Strohecker \& Henning, 1967; Association of Official Analytical Chemists, 2005). The results were expressed in $\mathrm{mg}$ of ascorbic acid per $100 \mathrm{~g}$ of sample.

\subsection{Rheology}

The rheological analysis was performed on rheometer equipment (Brookfield R/S Plus- SST, EUA), with the spindle sensor (V3 40/20 model), with an upward rotation rate of 0 to $60 \mathrm{~s}$, and downward of 60 to $120 \mathrm{~s}$, accelerating for one minute and decelerating for another minute, collecting 50 measurement points, 25 per minute. The tests were carried out at a constant temperature of $25^{\circ} \mathrm{C}$ (Moura et al., 2017). The results of shear stress were obtained for each applied strain rate. The Power Law model (Equation 1) was adjusted to the experimental data by applying the linear regression technique, with the aid of the KaleidaGraph v 4.5.4 program.

$\tau=k \cdot \gamma^{n}$

where: $\tau$ is the shear stress $(\mathrm{Pa})$,

$\mathrm{k}$ is the consistency index $\left(\mathrm{Pa} . \mathrm{s}^{\mathrm{n}}\right)$,

$\gamma$ is the strain rate $\left(\mathrm{s}^{-1}\right)$ and $\mathrm{n}$ is the behavior index.

\subsection{Sensory analysis}

Sensory tests were performed only with samples with hydrocolloid (GG - 0.1, 0.2, and 0.3\%) to select the ideal concentration of GG for the acerola smoothies and to analyze 
its effect on the properties of flavor, aroma, color, and texture of this product.

For acceptance tests and Check-All-That-Apply (CATA), 100 untrained panelists of both sexes, aged 18 to 65 years were recruited according to their interest in participating and their consumption habits of acerola. The panelists evaluated approximately $10 \mathrm{~mL}\left(7 \pm 1{ }^{\circ} \mathrm{C}\right)$ of each smoothie. The tests were performed in individual booths and the samples were served monadically to the tasters in plastic cups encoded with random three-digit numbers. A glass of natural water also was provided to eliminate the residual taste in the mouth between the samples. The panelists evaluated the sensory attributes through the 9-point hedonic scale, associated with a numerical value (1: "Dislike extremely" to 9: "Like extremely") (Stone \& Sidel, 2004). This scale indicated how much the tasters liked or disliked the samples concerning the attributes of color, appearance, aroma, flavor, texture (softness), and overall impression. A 5-point structured scale was adopted for consumption intention, where 1 represents the minimum score (I would never drink it) and 5 the highest score (I would always drink it).

Then, the panelists filled out the CATA test, which presented a list of 28 terms related to the smoothie samples, in which the panelists should indicate which of these best described each formulation. The terms were selected based on preliminary tests made with possible panelists. The study was approved by the Research Ethics Committee (CEP), under opinion no. 1.829.642

\subsection{Statistical analysis}

The study was conducted in a completely randomized design, with three repetitions of each of the experiments, and the data were treated with the aid of the SAS 2020 1.3. The results obtained were submitted to analysis of variance (ANOVA) and compared using the Tukey (samples with GG) and Dunnett (for comparisons with the control) test at the level of 5\% probability. The results were expressed as means followed by standard deviations. For the rheology test, data were analyzed using the KaleidaGraph v 4.5.4 program. The data from the CATA test were processed by the XLSTAT- 2019 program version 0.7. The frequency of use of each sensory attribute was determined by counting the number of consumers who used this term to describe each sample, following standard procedures, according to Meyners et al. (2013). The Cochran Q test was used to identify significant differences between smoothie formulations (Silva et al., 2012).

\section{Results and discussion}

\subsection{Color coordinates}

The results obtained in the evaluation of the color properties of smoothie formulations are shown in Table 1 . There was a significant difference $(\mathrm{p} \leq 0.05)$ between the control and the formulations with GG in all evaluated properties, however, there was no difference among the samples with GG ( $p>0.05)$. Therefore, there was no interference of the hydrocolloid concentration in the color of the smoothies.

For the luminosity variable $\left(L^{*}\right)$, the control showed a relatively higher value than formulations with GG $(0.1,0.2$ and $0.3 \%)$, indicating that this gum made the samples darker. Possibly, the presence of GG may have increased the stability of acerola pigments, such as anthocyanins and carotenoids, during heating, retaining the color, which resulted in darker samples (Xu et al., 2019). On the other hand, it is suggested that in the control sample the pigments were partially degraded during heating (Andrés et al., 2016) and possibly resulted in a lighter colored sample. Zhao et al. (2020) analyzed red rice drinks with the presence of xanthan gum and vitamin C. They observed that xanthan gum increased the color stability of the samples when compared to the control. A similar phenomenon may have occurred in this study with the use of gellan gum in smoothie samples.

For the variables $\mathrm{a}^{\star}$ (red to green color) and $\mathrm{b}^{\star}$ (yellow to blue color), the GG samples resulted in values higher than the control, located in the red and yellow color bands, which indicates that there was better maintenance of red color, possibly associated with the concentration of anthocyanin in the acerola pulp (Jaeschke et al., 2016). Leal et al. (2020) elaborated mangoacerola bars with hydrocolloids addition and reported that the samples with GG show an intense red color, demonstrating that the hydrocolloid may interfere with the color of the products.

For the chroma $\left(\mathrm{c}^{\star}\right)$, which represents the color purity, and hue angle (intensity of the color) it was observed that the samples GG presented values higher than the control, indicating that the presence of GG, regardless of the concentration, intensified the color of the samples, with the predominance of the yellow color ( $\mathrm{o}$ closest to $90^{\circ},+\mathrm{b}^{*}$ ). The intensity of pigments is linked to complex biochemical changes involving the compounds, such as carotenoids, vitamin C, thiamine, riboflavin, niacin, calcium, and phosphorus (Malegori et al., 2017).

Table 1. Characterization of the color properties $\left(\mathrm{L}^{\star}, \mathrm{a}^{\star}, \mathrm{b}^{\star}, \mathrm{c}^{\star}\right.$ and $\left.{ }^{\circ} \mathrm{h}\right)$ e of the acerola smoothie samples with different concentrations of gellan gum.

\begin{tabular}{|c|c|c|c|c|c|}
\hline Samples & $L^{*}$ & $a^{*}$ & $b^{*}$ & $c^{*}$ & ${ }^{\circ} \mathrm{h}$ \\
\hline Control & $64.60 \pm 0.19$ & $15.39 \pm 15.39$ & $18.80 \pm 0.14$ & $24.30 \pm 0.21$ & $50.68 \pm 0.27$ \\
\hline GG $0.1 \%$ & $61.14 \pm 1.22^{\mathrm{a} \star}$ & $17.40 \pm 17.40^{\mathrm{a} \star}$ & $23.00 \pm 0.22^{\mathrm{a} *}$ & $28.84 \pm 0.38^{\mathrm{a} \star}$ & $52.90 \pm 0.30^{a x}$ \\
\hline GG $0.2 \%$ & $62.49 \pm 0.19^{a \star}$ & $17.25 \pm 17.25^{\mathrm{a} \star}$ & $23.07 \pm 0.19^{a \star}$ & $28.81 \pm 0.27^{\mathrm{a} \star}$ & $53.21 \pm 0.20^{a x}$ \\
\hline GG $0.3 \%$ & $60.96 \pm 0.35^{\mathrm{a} \star}$ & $17.84 \pm 17.84^{\text {a }}$ & $23.46 \pm 0.12^{\mathrm{a} \star}$ & $29.46 \pm 0.21^{\mathrm{a} \star}$ & $52.76 \pm 0.19^{a x}$ \\
\hline
\end{tabular}

${ }^{*}$ Represents a verages in the same column present a significant difference in comparison to the control at the $5 \%$ probability level by the Dunnett test (p $\leq 0.05$ ). Means followed by equal letters do not differ significantly at the $5 \%$ probability level by the Tukey test. GG $=$ Gellan Gum. 
These findings are in agreement with the studies by Xu et al. (2019), who stated that the addition of GG in beverages containing anthocyanins in the presence of ascorbic acid promoted the reduction of color loss caused by heat treatment, improving its stability. These results infer that the hydrocolloid utilized probably favored color intensification of smoothies, which can contribute to the product becoming more sensorially attractive.

\subsection{Physico-chemical analysis}

The results of the physical-chemical properties of the acerola smoothies with and without GG are available in Table 2. The average values of $\mathrm{pH}$ and TA did not show a significant difference at $5 \%$ significance between the samples and the control, in contrast to the AA and TSS in which the control differed statistically $(\mathrm{p} \leq 0.05)$ comparing to the formulations $(0.1 \%, 0.2 \%$ and $0.3 \%)$. The samples containing GG did not differ among them in all the evaluated properties.

For AA, the control sample showed slightly higher mean values $(448.89 \mathrm{mg} / 100 \mathrm{~g})$ compared to the other formulations, suggesting that the use of GG between 0.1 and $0.3 \%$ in acerola smoothie did not result in large AA losses. Lower AA values for formulations with GG may be due to the entrapment of the AA in GG gel networks (Xu et al., 2019. On the other hand, even with lower values of vitamin $\mathrm{C}$ comparing to the control, smoothies containing GG still showed high values of this nutrient, since the recommended intake of this nutrient is $45 \mathrm{mg}$ per day for healthy adults (Brasil, 2005).

For soluble solids content found that all smoothie formulations containing GG showed statistically higher values ( $\mathrm{p} \leq 0.05$ ) than the control sample. The result can be justified due to the interaction of sucrose with the LAG during the formation of the gel network, promoting the suspension of this disaccharide (Morris et al., 2012).

According to Sancho et al. (2007), the variability of this parameter can be explained, in principle, by the variation of the ${ }^{\circ}$ Brix of the raw material itself and the friction between the sample particles and the surface of the processing site, resulting in a greater breakdown of the pulp and polysaccharides and thus, promoting an increase in the content of soluble solids. For $\mathrm{pH}$ and total acidity, the samples with GG were shown to be the same as the control formulation, which implies that the use of this hydrocolloid does not influence the concentration of organic acids in beverages like acerola smoothies. The high acidity characteristic of the acerola pulp, with $\mathrm{pH}$ between 2.9 to 3.68 (Maciel et al., 2010; Souza et al., 2014) contributed for this parameter to remain low in smoothie samples, which contributes to its conservation, and act as a barrier for the growth of pathogenic microorganisms (Ribeiro et al., 2018).

\subsection{Rheology}

In Figure 1, it can be seen that there is no linear relationship between the shear stress and the strain rate of the samples, indicating the non-Newtonian behavior of the product (Wei et al., 2001). Table 3 presents the values of the samples' consistency index and behavior after adjusting to the Power Law model of the shear stress results as a function of the change in the strain rate.
Table 2. Physico-chemical characterization of acerola smoothie samples with different concentrations of gellan gum.

\begin{tabular}{lcccc}
\hline Samples & $\begin{array}{c}\text { Ascorbic } \\
\text { Acid (AA) }\end{array}$ & TSS ( ${ }^{\circ}$ Brix) & $\begin{array}{c}\text { Titratable } \\
\text { Acidity (AT) }\end{array}$ & pH \\
\hline Control & $448.89 \pm 2.56$ & $16.03 \pm 0.06$ & $0.56 \pm 0.02$ & $4.15 \pm 0.01$ \\
GG 0.1\% & $425.99 \pm 0.88^{\mathrm{a} *}$ & $17.10 \pm 0.10^{\mathrm{a} *}$ & $0.56 \pm 0.02^{\mathrm{a}}$ & $4.17 \pm 0.03^{\mathrm{a}}$ \\
GG 0.2\% & $422.18 \pm 2.37^{\mathrm{a}}$ & $17.07 \pm 0.15^{\mathrm{a}}$ & $0.56 \pm 0.01^{\mathrm{a}}$ & $4.15 \pm 0.03^{\mathrm{a}}$ \\
GG 0.3\% & $430.49 \pm 3.70^{\mathrm{a}}$ & $17.23 \pm 0.06^{\mathrm{a}}$ & $0.56 \pm 0.01^{\mathrm{a}}$ & $4.13 \pm 0.02^{\mathrm{a}}$ \\
\hline
\end{tabular}

${ }^{*}$ Averages in the same column present a significant difference in comparison to the control at the $5 \%$ probability level by the Dunnett test $(p \leq 0.05)$. Means followed by equal letters do not differ significantly at the $5 \%$ probability level by the Tukey test. GG $=$ Gellan Gum. AA = mg ascorbic acid $/ 100 \mathrm{~g}$ sample; $\mathrm{AT}=\mathrm{g}$ citric acid $/ 100 \mathrm{~g}$ sample.

Table 3. Consistency index (k) and behavior index (n) of smoothies with different levels of gellan gum.

\begin{tabular}{ccc}
\hline Samples & $\mathrm{k}$ & $\mathrm{n}$ \\
\hline Controle & $0.20 \pm 0.02^{\mathrm{a}}$ & $0.83 \pm 0.06^{\mathrm{a}}$ \\
GG $0.1 \%$ & $1.43 \pm 0.09^{\mathrm{b}}$ & $0.44 \pm 0.03^{\mathrm{b}}$ \\
GG $0.2 \%$ & $6.96 \pm 0.48^{\mathrm{c}}$ & $0.25 \pm 0.01^{\mathrm{c}}$ \\
GG 0.3\% & $14.72 \pm 1.18^{\mathrm{d}}$ & $0.19 \pm 0.01^{\mathrm{d}}$ \\
\hline
\end{tabular}

Means followed by at least one equal letter in the same column, do not differ significantly at the level of $5 \%$ probability by the Tukey test. GG = Gellan Gum.

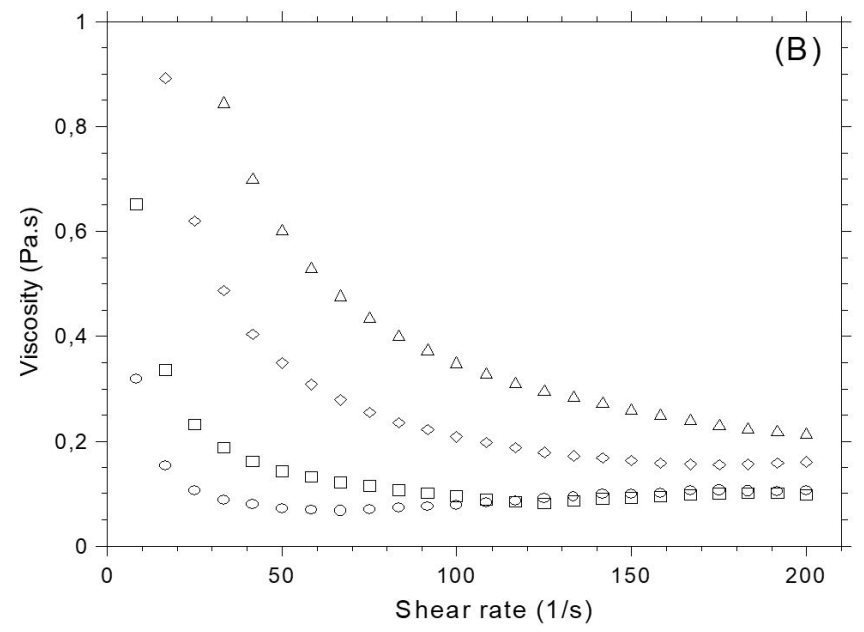

Figure 1. (A) Flow curve of smoothies with different concentrations of gellan. (B) Viscosity as a function of the shear rate of smoothies with different concentrations of GG. Control (०), GG 0.1\% (口), GG $0.2 \%$ $(\diamond)$ e GG $0.3 \%(\triangle)$.

The data were well fitted to the power-law model for all samples $\left(R^{2}>0.98\right)$ and the values of " $n$ " (behavior index) were less than 1 , showing that all formulations have their rheological behavior classified as being of a pseudoplastic fluid (Steffe, 1996). It can be seen that the behavior index decreases as the hydrocolloid concentration increases, showing an increase in the pseudoplastic behavior of the samples (Mitsoulis, 2010). The present study showed results similar to those reported by Ribeiro et al. (2019) who studied the rheological behavior of juçara, banana and strawberry smoothies, where all systems presented $\mathrm{n}<1.0$ indicating pseudoplastic behavior and good adjustment to the Power Law. The consistency index (k) increased as the GG concentration increased, that is, the higher the concentration of 
that hydrocolloid, the greater the sample consistency index (k). It is explained by the higher concentration of GG, which forms a more structured network, once more interaction between the polymeric chains occurs (Phillips \& Williams, 2009).

The apparent viscosities of all samples showed similar behavior as the strain rate increased, characterized by a rapid decrease in viscosity at lower strain rates followed by a slower decrease in higher strain rates. This behavior is typical of pseudoplastic fluids (Kaur \& Kaur, 2020) and is explained by the rearrangement of polymeric gellan chains that occurs at higher shear rates. The results were similar to those found by Sherafati et al. (2013); when evaluating the rheological aspects of carrot juice with different proportions $(0.02,0.025$ and $0.03 \%)$ of low and high acylation GG (LA and HA), they also observed pseudoplastic behavior in the evaluated drink, and that the concentration of GG, heat treatment and carrot juice had a good potential to alter the flow index and the coefficient of consistency of the drink.

\subsection{Sensory analysis}

\section{Acceptance test}

The averages for the acceptance test of the smoothie samples are available in Table 4. It can be observed that there was no significant difference $(\mathrm{p}>0.05)$ for the appearance and aroma attributes, with averages corresponding to the hedonic term "Liked moderately". For the other attributes evaluated, the samples were statistically different $(\mathrm{p} \leq 0.05)$.

For the color attribute, the averages were between the terms "Liked slightly" and "Liked moderately", with a statistical difference $(\mathrm{p} \leq 0.05)$ between the samples $0.1 \%$ and $0.3 \%$. Regarding the texture, it can be seen that the $0.2 \%$ sample obtained a higher average acceptance, corresponding to the term "Liked moderately", and the other formulations were placed between the terms "Neither like nor dislike" and "Like slightly". Therefore, it is observed that the tasters showed greater acceptance of the sample with an intermediate texture $(0.2 \%)$. This can be explained by the increase of GG concentration, which promoted an increase in the samples' viscosity (Banerjee et al., 2013). Regarding the attributes of flavor and global impression, the samples showed averages that varied between the terms "Neither like nor dislike" and "Liked moderately", with the formulation $0.3 \%$ being less accepted for

Table 4. Averages of the sensory acceptance test for acerola smoothies made with gellan gum.

\begin{tabular}{lccc}
\hline \multirow{2}{*}{ Attributes } & \multicolumn{3}{c}{ Gellan Gum Concentration } \\
\cline { 2 - 4 } & $0.1 \%$ & $0.2 \%$ & $0.3 \%$ \\
\hline Appearance & $6.65 \pm 1.67^{\mathrm{a}}$ & $7.08 \pm 1.62^{\mathrm{a}}$ & $6.72 \pm 1.61^{\mathrm{a}}$ \\
Color & $6.71 \pm 1.66^{\mathrm{b}}$ & $7.12 \pm 1.45^{\mathrm{ab}}$ & $7.28 \pm 1.25^{\mathrm{a}}$ \\
Aroma & $6.77 \pm 1.63^{\mathrm{a}}$ & $6.91 \pm 1.60^{\mathrm{a}}$ & $6.73 \pm 1.69^{\mathrm{a}}$ \\
Texture & $6.21 \pm 1.71^{\mathrm{b}}$ & $7.01 \pm 1.51^{\mathrm{a}}$ & $5.69 \pm 2.18^{\mathrm{b}}$ \\
Flavor & $6.15 \pm 2.05^{\mathrm{ab}}$ & $6.73 \pm 2.03^{\mathrm{a}}$ & $5.58 \pm 1.93^{\mathrm{b}}$ \\
Global & $6.19 \pm 1.85^{\mathrm{ab}}$ & $6.78 \pm 1.69^{\mathrm{a}}$ & $5.95 \pm 1.85^{\mathrm{b}}$ \\
Impression & & & \\
Consumption & $2.78 \pm 1.12^{\mathrm{b}}$ & $3.29 \pm 1.16^{\mathrm{a}}$ & $2.65 \pm 1.06^{\mathrm{b}}$ \\
intention & & & \\
\hline
\end{tabular}

Means with the same letter on the same line do not differ at the $5 \%$ level of significance for the Tukey test. these attributes. The lower acceptance of this formulation in the flavor parameter may be related to the higher intensity of acid taste in higher concentrations of low acyl gellan gum, since it is less associated as an ideal characteristic, according to Leal et al. (2021). In addition, the increase in the hydrocolloid concentration increased the viscosity of the drinks and, consequently, the intensity of flavor was less perceived by the tasters, since high viscosity levels can reduce or eliminate the taste of food products (Wagoner et al., 2020). For consumption intention, it is observed that the averages were classified according to the terms of the hedonic scale "I would rarely drink it" and "I would drink it occasionally". Of the three formulations, the $0.2 \%$ sample obtained the highest average (3.29), therefore, more accepted by the tasters. Guazi et al. (2019) observed low acceptance for smoothies made with banana/apple pulps, the authors justified it by the novelty of the product and its low sugar content.

\section{Check-all-that-apply (CATA)}

Significant differences $(\mathrm{p} \leq 0.05)$ were found in 14 of the 28 attributes used to describe the acerola smoothie samples, being the terms "homogeneous", "yellowish color", "soft", "acerola flavor" and "acerola aroma" those that presented higher frequencies (Table 5).

Table 5. Frequency of Check-All-That-Apply (CATA) using the Cochran $\mathrm{Q}$ test to compare samples of acerola smoothie.

\begin{tabular}{|c|c|c|c|}
\hline \multirow[b]{2}{*}{ Attributes } & \multicolumn{3}{|c|}{ Gellan Gum Concentration } \\
\hline & $0.1 \%$ & $0.2 \%$ & $0.3 \%$ \\
\hline Homogeneous & $35^{\mathrm{b}}$ & $49^{\mathrm{a}}$ & $36^{\mathrm{ab}}$ \\
\hline Bright & $14^{\mathrm{b}}$ & $20^{\mathrm{b}}$ & $43^{a}$ \\
\hline Pale color & $22^{\mathrm{a}}$ & $8^{\mathrm{b}}$ & $9^{b}$ \\
\hline Pinkish red color & $2^{\mathrm{b}}$ & $0^{\mathrm{b}}$ & $75^{a}$ \\
\hline Yellowish color & $66^{\mathrm{a}}$ & $77^{a}$ & $5^{b}$ \\
\hline Presence of liquid & $2^{\mathrm{ab}}$ & $0^{\mathrm{b}}$ & $1^{\mathrm{a}}$ \\
\hline Firm & $4^{\mathrm{b}}$ & $22^{a}$ & $28^{a}$ \\
\hline Soft & $44^{\mathrm{a}}$ & $37^{\text {a }}$ & $42^{\mathrm{a}}$ \\
\hline Presence of foam & $20^{\mathrm{b}}$ & $13^{\mathrm{b}}$ & $41^{\mathrm{a}}$ \\
\hline Gelatinous & $5^{b}$ & $26^{\mathrm{a}}$ & $3^{b}$ \\
\hline Astringent & $1^{\text {a }}$ & $2^{\mathrm{a}}$ & $7^{\mathrm{a}}$ \\
\hline Sandy & $11^{\mathrm{a}}$ & $5^{\mathrm{a}}$ & $12^{\mathrm{a}}$ \\
\hline Liquid & $77^{\mathrm{a}}$ & $36^{\mathrm{b}}$ & $26^{\mathrm{b}}$ \\
\hline Juicy & $11^{\mathrm{a}}$ & $18^{a}$ & $16^{\mathrm{a}}$ \\
\hline Fruit aroma & $32^{a}$ & $40^{\mathrm{a}}$ & $33^{\mathrm{a}}$ \\
\hline Acid aroma & $23^{a}$ & $21^{a}$ & $18^{\mathrm{a}}$ \\
\hline Sweet aroma & $33^{\mathrm{a}}$ & $26^{\mathrm{ab}}$ & $14^{\mathrm{b}}$ \\
\hline Acerola aroma & $52^{\mathrm{a}}$ & $54^{\mathrm{a}}$ & $49^{a}$ \\
\hline Cooked acerola aroma & $7^{\text {a }}$ & $6^{\mathrm{a}}$ & $6^{\mathrm{a}}$ \\
\hline Acidic taste & $22^{b}$ & $23^{b}$ & $46^{\mathrm{a}}$ \\
\hline Sweet taste & $22^{a}$ & $19^{\mathrm{a}}$ & $10^{\mathrm{a}}$ \\
\hline Fruit flavor & $37^{\mathrm{a}}$ & $38^{a}$ & $19^{\mathrm{b}}$ \\
\hline Acerola flavor & $65^{a}$ & $63^{a}$ & $34^{\mathrm{b}}$ \\
\hline Milk flavor & $33^{\mathrm{a}}$ & $26^{\mathrm{a}}$ & $22^{\mathrm{a}}$ \\
\hline Yogurt flavor & $7^{a}$ & $13^{\mathrm{a}}$ & $8^{a}$ \\
\hline Fresh acerola flavor & $6^{a}$ & $9^{a}$ & $7^{a}$ \\
\hline Strange taste & $14^{\mathrm{a}}$ & $16^{\mathrm{a}}$ & $19^{\mathrm{a}}$ \\
\hline
\end{tabular}

Means with the same letters, in the same line, do not differ at the $5 \%$ level of significance for the Cochran Q test ( $p>0.05$ ). 
The $0.1 \%$ formulation showed higher frequencies of the attributes "pale color", "liquid" and "sweet aroma". The most liquid texture of the formulation containing the lowest hydrocolloid concentration occurred, according to Banerjee et al. (2013), when the hardness of the gel increases as the hydrocolloid concentration is increased. The "homogeneous" attribute was more related to the $0.2 \%$ formulation. In turn, the $0.3 \%$ sample was more characterized by the keywords "bright", "pinkish-red color" and "acidic taste", being less associated with the attributes "yellowish color", "fruit flavor" and "acerola flavor". Based on this result, it was observed that the use of a higher concentration of hydrocolloid resulted in stronger gels, which possibly contributed to making the product brighter and enhanced the intensity of the red color of the acerola. However, a higher concentration of hydrocolloid resulted in reduced taste, which is expected in rigid and firm gels with less flavor release, in addition to a grainy appearance (Bayarri et al., 2007; Morris et al., 2012). This corroborates with the results of hedonic tests, which showed a lower average of acceptance in the flavor attribute for a sample of $0.3 \%$. In the supplementary material (Figure S1), principal coordinate analysis is available for the global impression attributes according to CATA terms.

\section{Conclusion}

The use of GG for the production of acerola smoothie allowed the development of a drink with a fluid gel aspect, with pseudoplastic behavior, higher viscosity, and intense red color. The different concentrations of GG $(0.1,0.2$, and $0.3 \%)$ did not interfere in the physical-chemical properties of the samples and the levels of ascorbic acid, although they have reduced, remained high when compared to the control. The concentration of $0.2 \%$ presented higher acceptance averages for appearance and flavor, being the most attractive for consumers. GG can be an ally in the production of smoothies or similar drinks, making it possible to use the fluid gel production technique with other fruits or vegetables and thereby make combinations that may result in products with nutritional quality and standardized textures.

\section{References}

Albuquerque, A. C. S., \& Silva, A. G. (2008). Agricultura tropical: quatro décadas de inovações tecnológicas, institucionais e políticas. Brasília, DF: Embrapa Informação Tecnológica.

Andrés, V., Mateo-Vivaracho, L., Guillamón, E., Villanueva, M. J., \& Tenorio, M. D. (2016). High hydrostatic pressure treatment and storage of soy-smoothies: colour, bioactive compounds and antioxidant capacity. Food Science and Technology, 69, 123-130.

Association of Official Analytical Chemists - AOAC (2005). Official methods of analysis of the Association of Official Analytical Chemistry. (18th ed.). Washington, DC: Association of Official Analytical Chemists.

Banerjee, S., Ravi, R., \& Bhattacharya, S. (2013). Textural characterization of gellan and agar based fabricated gels with carrot juice. Food Science and Technology, 53(1), 255-261.

Bayarri, S., Rivas, I., Izquierdo, L., \& Costell, E. (2007). Influence of texture on the temporal perception of sweetness of gelled systems. Food Research International, 40(7), 900-908. http://dx.doi.org/10.1016/j. foodres.2007.03.003.
Belwal, T., Devkota, H. P., Hassan, H. A., Ahluwalia, S., Ramadan, M. F., Mocan, A., \& Atanasov, A. G. (2018). Phytopharmacology of acerola (Malpighia spp.) \& its potential as functional food. Trends in Food Science \& Technology, 74, 99-106. http://dx.doi.org/10.1016/j. tifs.2018.01.014.

Brasil, Agência Nacional de Vigilância Sanitária - Anvisa. (2005, September 23). Resolução RDC № 269, de 22 de setembro de 2005. Aprova o Regulamento Técnico sobre a Ingestão Diária Recomendada (IDR) de Proteína, Vitaminas e Minerais. Diário Oficial [da] República Federativa do Brasil..

Camargo, F. A. O., Camargo, A. S. O., Abreu, A. J., Ferreira, E. B., Azeredo, E. M. C., \& Lucia, F. D. (2020). Acceptability of strawberry and banana smoothie drinks prepared with oat different concentrations. Brazilian Journal of Development, 6(11), 84642-84657. http://dx.doi. org/10.34117/bjdv6n11-033.

Cano-Lamadrid, M., Hernández, F., Nowicka, P., Carbonell-Barrachina, A. A., \& Wojdyło, A. (2018). Formulation and storage effects on pomegranate smoothie phenolic composition, antioxidant capacity and color. Food Science and Technology, 96, 322-328..

Fernandez, M. V., Denoya, G. I., Jagus, R. J., Vaudagna, S. R., \& Agüero, M. V. (2019). Microbiological, antioxidant and physicochemical stability of a fruit and vegetable smoothie treated by high pressure processing and stored at room temperature. Food Science and Technology, 105, 206-210.

Funami, T. (2011). Next target for food hydrocolloid studies: texture design of foods using hydrocolloid technology. Food Hydrocolloids, 25(8), 1904-1914. http://dx.doi.org/10.1016/j.foodhyd.2011.03.010.

Guazi, J. S., Lago-Vanzela, E. S., \& Conti-Silva, A. C. (2019). Development of smoothies from dehydrated products of strawberry and banana pulps obtained through foam-mat drying. International Journal of Food Science \& Technology, 54(1), 54-61. http://dx.doi.org/10.1111/ ijfs. 13900 .

Hurtado, A., Guàrdia, M. D., Picouet, P., Jofré, A., Ros, J. M., \& Bañón, S. (2017). Stabilization of red fruit-based smoothies by high-pressure processing. Part A: effects on microbial growth, enzyme activity, antioxidant capacity \& physical stability. Journal of the Science of Food and Agriculture, 97(3), 770-776. http://dx.doi.org/10.1002/ jsfa.7796. PMid:27170492.

Jaeschke, D. P., Marczak, L. D. F., \& Mercali, G. D. (2016). Evaluation of non-thermal effects of electricity on ascorbic acid and carotenoid degradation in acerola pulp during ohmic heating. Food Chemistry, 199, 128-134. http://dx.doi.org/10.1016/j.foodchem.2015.11.117. PMid:26775953.

Kaur, R., \& Kaur, K. (2020). Effect of processing on color, rheology and bioactive compounds of different sweet pepper purees. Plant Foods for Human Nutrition, 75(3), 369-375. http://dx.doi.org/10.1007/ s11130-020-00824-0. PMid:32394018.

Keenan, D. F., Brunton, N. P., Gormley, T. R., Butler, F., Tiwari, B. K., \& Patras, A. (2010). Effect of thermal and high hydrostatic pressure processing on antioxidant activity and colour of fruit smoothies. Innovative Food Science \& Emerging Technologies, 11(4), 551-556. http://dx.doi.org/10.1016/j.ifset.2010.07.003.

Leal, A. R., Costa, J. N., Vieira, J. M. M., Araújo, A. A. L. Fo., \& Sousa, P. H. M. (2020). Mango with cashew apples structured: influence of honey and gellan gum on physical-chemical and sensorial characteristics. Research, Society and Development, 9(5), e96953253. http://dx.doi.org/10.33448/rsd-v9i5.3253.

Leal, A. R., Oliveira, L. S., Farias, L. M., Alves, C. A. N., Costa, J. N., Mata, P., \& Sousa, P. H. M. (2021). Elaboration of mixed structured fruit formulations with agar and gellan gum: texture, physicochemical, 
and sensory properties. International Journal of Gastronomy and Food Science, 23, 100294. http://dx.doi.org/10.1016/j.ijgfs.2020.100294.

Leffa, D. D., Santos, C. E. I., Daumann, F., Longaretti, L. M., Amaral, L., Dias, J. F., Silva, J., \& Andrade, V. M. (2015). Effects of supplemental acerola juice on the mineral concentrations in liver and kidney tissue samples of mice fed with cafeteria diet. Biological Trace Element Research, 167, 70-76. http://dx.doi.org/10.1007/s12011-015-0276-9. PMid:25724149.

Lemos, D. M., Rocha, A. P. T., Gouveia, J. P. G., Oliveira, E. N. A., Sousa, E. P., \& Silva, S. F. (2019). Elaboração e caracterização de geleia prebiótica mista de jabuticaba e acerola. Brazilian Journal of Food Technology, 22, e2018098. http://dx.doi.org/10.1590/1981-6723.09818.

Maciel, M. I. S., Melo, E., Lima, V., Souza, K. A., \& Silva, W. (2010). Physicochemical characterization of fruits from genotypes of acerola tree (Malpighia emarginata D.C.). Food Science and Technology, 30(4), 865-869. https://doi.org/10.1590/S0101-20612010000400005.

Malegori, C., Marques, E. J. N., Freitas, S. T., Pimentel, M. F., Pasquini, C. \& Casiraghi, E. (2017). Comparing the analytical performances of Micro-NIR and FT-NIR spectrometers in the evaluation of acerola fruit quality, using PLS and SVM regression algorithms. Talanta, 165, 112-116. https://doi.org/10.1016/j.talanta.2016.12.035.

Meyners, M., Castura, J. C., \& Carr, B. T. (2013). Existing and new approaches for the analysis of CATA data. Food Quality and Preference, 30(2), 309-319. http://dx.doi.org/10.1016/j.foodqual.2013.06.010.

Mitsoulis, E. (2010). Fountain flow of pseudoplastic and viscoplastic fluids. Journal of Non-Newtonian Fluid Mechanics, 165(1-2), 45-55. http://dx.doi.org/10.1016/j.jnnfm.2009.09.001.

Morris, E. R., Nishinari, K., \& Rinaudo, M. (2012). Gelation of gellan: a review. Food Hydrocolloids, 28(2), 373-411. http://dx.doi.org/10.1016/j. foodhyd.2012.01.004.

Moura, S. C. S. R., Vissotto, F. Z., Berbari, S. A. G., Souza, E. C. G., Toti, F. G. P., \& Alves, P. Jr. (2017). Characterization and evaluation of stability of bioactive compounds in fruit smoothies. Food Science and Technology, 37(2), 216-223. http://dx.doi.org/10.1590/1678457x.16616.

Phillips, G. O., \& Williams, P. A. (2009). Handbook of hydrocolloids. Boca Raton: CRC Press. http://dx.doi.org/10.1533/9781845695873.

Ribeiro, L.O., Barbosa, I. C., Sá, D. G. C. F., Silva, J. P. L., Matta, V. M., \& Freitas, S. P. (2020). Stability evaluation of juçara, banana and strawberry pasteurized smoothie during storage. Food Science and Technology, 40(2), 387-393. https://doi.org/10.1590/fst.01319.

Ribeiro, L. O., Pinheiro, A. C. B., Brígida, A. I. S., Genisheva, Z. A., Vicente, A. A. M. O. S., Teixeira, J. A. C., Matta, M., \& Freitas, S. P. (2019). In vitro gastrointestinal evaluation of a juçara-based smoothie: effect of processing on phenolic compounds bioaccessibility. Journal of Food Science and Technology, 56(11), 5017-5026. http://dx.doi. org/10.1007/s13197-019-03974-5. PMid:31741526.

Ribeiro, L. O., Santos, J. G. C., Gomes, F. S., Cabral, L. M. C., Sá, D. G. C. F., Matta, V. M., \& Freitas, S. P. (2018). Sensory evaluation and antioxidant capacity as quality parameters in the development of a banana, strawberry and juçara smoothie. Food Science and Technology, 38(4), 653-660. http://dx.doi.org/10.1590/1678-457x.12017.

Sancho, S. O., Maia, G. A., Figueiredo, R. W., Rodrigues, S., \& Sousa, P. H. M. (2007). Alterações químicas e físico-químicas no processamento de suco de caju (Anacardium occidentale L.). Food
Science and Technology, 24(4), 878-882. http://dx.doi.org/10.1590/ S0101-20612007000400031.

Sherafati, M., Kalbasi-Ashtari, A., \& Mousavi, S. M. A. (2013). Effects of low and high acyl gellan gums on engineering properties of carrot juice. Journal of Food Process Engineering, 36(4), 418-427. http:// dx.doi.org/10.1111/j.1745-4530.2012.00682.x.

Silva, R. C. S. N., Minim, V. P. R., Simiqueli, A. A., Moraes, L. E. S., Gomide, A. I., \& Minim, L. A. (2012). Optimized descriptive profile: a rapid methodology for sensory description. Food Quality and Preference, 24(1), 190-200. http://dx.doi.org/10.1016/j.foodqual.2011.10.014.

Souza, K. O., Moura, C. F. H., Brito, E. S., \& Miranda, M. R. A. (2014). Compostos antioxidantes e atividade antioxidante total em frutos de acerola da cv. Flor Branca, Florida Sweet e BRS 366. Revista Brasileira de Fruticultura, 36(2), 294-304. http://dx.doi.org/10.1590/01002945-410/13.

Steffe, J. F. (1996). Rheological methods in food process engineering (2nd ed.). East Lansing: Freeman Press.

Stone, H., \& Sidel, J. L. (2004). Sensory evaluation practices (3rd ed.). New York: Academic Press.

Strohecker, R., \& Henning, H. M. (1967). Analisis de vitaminas: métodos comprobados. Madrid: Paz Montalvo.

Teleszko, M., \& Wojdyło, A. (2014). Bioactive compounds vs. organoleptic assessment of 'smoothies'-type products prepared from selected fruit species. International Journal of Food Science \& Technology, 49(1), 98-106. http://dx.doi.org/10.1111/ijfs.12280.

Wagoner, T. B., Çakır-Fuller, E., Shingleton, R., Drake, M., \& Foegeding, E. A. (2020). Viscosity drives texture perception of protein beverages more than hydrocolloid type. Journal of Texture Studies, 51(1), 7891. PMid:31323134.

Wei, Y. P., Wang, C. S., \& Wu, J. S. B. (2001). Flow properties of fruit fillings. Food Research International, 34(5), 377-381. http://dx.doi. org/10.1016/S0963-9969(00)00178-2.

Xu, M., Shen, C., Zheng, H., Xu, Y., Xue, C., Zhu, B., \& Hu, J. (2020). Metabolomic analysis of acerola cherry (Malpighia emarginata) fruit during ripening development via UPLC-Q-TOF \& contribution to the antioxidant activity. Food Research International, 130, 108915. http://dx.doi.org/10.1016/j.foodres.2019.108915. PMid:32156365.

Xu, X. J., Fang, S., Li, Y. H., Zhang, F., Shao, Z. P., Zeng, Y. T., Chen, J., \& Meng, Y. C. (2019). Effects of low acyl and high acyl gellan gum on the thermal stability of purple sweet potato anthocyanins in the presence of ascorbic acid. Food Hydrocolloids, 86, 116-123. http:// dx.doi.org/10.1016/j.foodhyd.2018.03.007.

Young, P. W., Mills, T. B., \& Norton, I. T. (2020). Influence of $\mathrm{pH}$ on fluid gels produced from egg \& whey protein isolate. Food Hydrocolloids, 26, 106108 .

Zhao, L., Pan, F., Mehmood, A., Zhang, Y., Hao, S., Rehman, A. U., Li, J., Wang, C., \& Wang, Y. (2020). Protective effect and mechanism of action of xanthan gum on the color stability of black rice anthocyanins in model beverage systems. International Journal of Biological Macromolecules, 164, 3800-3807. http://dx.doi.org/10.1016/j. ijbiomac.2020.09.027. PMid:32910958.

Zia, K. M., Taasum, S., Khan, M. F., Akram, N., Akhter, N., Noreen, A., \& Zuber, M. (2018). Recent trends on gellan gum blends with natural \& synthetic polymers: a review. International Journal of Biological Macromolecules, 109(1), 1068-1087. http://dx.doi.org/10.1016/j. ijbiomac.2017.11.099. PMid:29157908. 


\section{Supplementary Material}

Supplementary material accompanies this paper.

Figure S1. Principal Coordinate Analysis for the global impression attributes according to the CATA terms.

This material is available as part of the online article from https://www.scielo.br/j/CTA. 